\title{
VALUING PROCESS OVER PRODUCT: USING WRITING TO TEACH HISTORY IN THE UNDERGRADUATE HISTORY CLASSROOM
}

\author{
Genesea M. Carter \\ Colorado State University \\ David Korostyshevsky \\ Colorado State University and the University of Denver
}

\begin{abstract}
History is as much a writing field as literature, yet few historians are trained in how to teach writing, as graduate students in literature usually are. Most required composition courses are taught by English departments and are explicitly interdisciplinary. This often leaves history instructors scrambling to find ways to address writing in our own discipline-specific ways with little direct training or curriculum space devoted to it.
\end{abstract}

-Katherine Pickering Antonova ${ }^{1}$

Katherine Pickering Antonova's The Essential Guide to Writing History Essays is a favorite recommendation among historians on Facebook and Twitter. While there has been growing research and guidance offered about teaching K-12 students how to write in the history classroom, Antonova's work fills an important gap for how to teach the essay in the undergraduate and graduate history classroom. ${ }^{2}$ Antonova's Essential Guide represents the latest within the genre of history writing guides that have always focused exclusively on essay writing, such as end-of-term research papers and midterms. ${ }^{3}$ While many history faculty might be inclined to predominantly assign essay-writing guides like Antonova's, this method alone is not sufficient to teach students to think about complex new information and express their ability to interpret historical information at the university level. ${ }^{4}$

\footnotetext{
${ }^{1}$ Katherine Pickering Antonova, The Essential Guide to Writing History Essays (Oxford: Oxford University Press, 2020), xv.

${ }^{2}$ See especially Chauncey Monte-Sano, "Qualities of Historical Writing Instruction: A Comparative Case Study of Two Teachers' Practices," American Educational Research Journal 45, no. 4 (2008): 1045-1079; Chauncey Monte-Sano, "Beyond Reading Comprehension and Summary: Learning to Read and Write in History by Focusing on Evidence, Perspective, and Interpretation," Curriculum Inquiry 41, no. 2 (2011): 212-249; Chauncey Monte-Sano et al., Reading, Thinking, and Writing About History: Teaching Argument Writing to Diverse Learners in the Common Core Classroom, Grades 6-12 (New York: Teachers College Press, 2014); Chauncey Monte-Sano, "Argumentation in History Classrooms: A Key Path to Understanding the Discipline and Preparing Citizens," Theory Into Practice 55, no. 4 (October 1, 2016): 311-319; Chauncey Monte-Sano and Amina Allen, "Historical Argument Writing: The Role of Interpretive Work, Argument Type, and Classroom Instruction," Reading and Writing 32 , no. 6 (June 1, 2019): 1383-1410.

${ }^{3}$ For example, see William Kelleher Storey, Writing History: A Guide for Students, 6th edition (New York: Oxford University Press, 2020); Mary Lynn Rampolla, A Pocket Guide to Writing in History, 10th edition (Boston: Bedford/St. Martin's, 2020); Richard Marius and Melvin Eugene Page, A Short Guide to Writing about History (Pearson, 2015).

${ }^{4}$ Over the last several decades, university history pedagogy has moved from an emphasis on teaching historical content to teaching that history is an endeavor, a shift that renders history as an interpretive act that a historian does, not an objective record of events that the historian discovers. On these pedagogical trends, see "AHA History Tuning Project: 2016 History Discipline Core," https:// www.historians.org/teaching-and-learning/tuning-the-history-discipline/2016-history-discipline-core; Lendol Calder, "Uncoverage: Toward a Signature Pedagogy for the History Survey," Journal of American History 92, no. 4 (March 1, 2006): 1358-1370; Michael Coventry, et al., "Ways of Seeing: Evidence and Learning in the History Classroom," Journal of American History 92 , no. 4 (March 1, 2006): 1371-1402; Joel M. Sipress and David J. Voelker, "From Learning History to Doing History: Beyond the Coverage Model," in Exploring Signature Pedagogies: Approaches to Teaching Disciplinary Habits of Mind, ed. Regan A. R. Gurung, et al. (Sterling, VA: Stylus Publishing, 2008), 19-35; Elizabeth Belanger, "How Now? Historical Thinking, Reflective Teaching, and the Next Generation of History Teachers," Journal of American History 97, no. 4 (March 1, 2011): 1079-1088; Joel M. Sipress and David J. Voelker, "The End of the History Survey Course: The Rise and Fall of the Coverage Model," Journal of American History 97, no. 4 (March 1, 2011): 1050-1066; David J. Voelker and Anthony Armstrong, "Designing a Question-Driven U.S. History Course," OAH Magazine of History 27, no. 3 (July 1, 2013): 19-24.
}

(C) 2021 Carter \& Korostyshevsky. Free to copy and share for education and scholarship under a Creative Commons Attribution NonCommercial-NoDerivatives 4.0 License. 
Indeed, the essay itself, a fundamental genre of historical writing, is not always the best way for students to grapple with new, complex, and controversial material. Rather, we urge history faculty to adopt what we call "a writing process mindset" and prioritize teaching history through the writing process rather than through cumulative assignments, such as research papers and midterms.

The concept of teaching history through the writing process is not new. University history faculty have advocated for the writing process since the 1990s. ${ }^{5}$ In this article, we extend these arguments by drawing from our twenty years of combined experience teaching writing in the composition and rhetoric and history classrooms to offer four recommendations for how university historians might teach history through the writing process: (1) through daily or weekly process writing (also called informal writing or low-stakes writing) to help students process their learning and questions; (2) through metacognitive writing assignments that ask students to reflect on their learning; (3) through faculty's primary grading emphasis on students' content rather than their grammar; and (4) through grade distribution. We make these recommendations with undergraduate history courses in mind, but they can be adopted across majors and non-majors courses as well as graduate history courses.

We recognize readers may feel some resistance at the idea of teaching history through the writing process and may respond with "I am a historian—not an English professor." ${ }^{6}$ However, this line of thinking discounts the research showing learning, and by extension writing, must be treated as a process. Teaching and learning scholars Susan A. Ambrose, Michael W. Bridges, Michele DiPierto, Marsha C. Lovett, and Marie K. Norman write, "Learning is a process that leads to change, which occurs as a result of experience and increases the potential for improved performance and future learning." When faculty across the disciplines adopt a writing process mindset, it directly contributes to students' learning through the development of their cognitive growth, analytical skills, close reading, and idea development, among other skills critical to their success in the history classroom and beyond. ${ }^{8}$

\section{What the Field of Rhetoric and Composition Offers Historians}

There are many university historians who are unfamiliar with the field of rhetoric and composition; therefore, we offer a very brief literature review of the field. Rhetoric and composition, also interchangeably referred to as "writing studies," focuses on "teaching [the] writing process and a commitment to writing pedagogy" and

\footnotetext{
${ }^{5}$ Stuart Greene, "The Problems of Learning to Think like a Historian: Writing History in the Culture of the Classroom," Educational Psychologist 29, no. 2 (March 1, 1994): 89-96; Stuart Greene, "The Question of Authenticity: Teaching Writing in a First-Year College History of Science Class," Research in the Teaching of English 35, no. 4 (2001): 525-569; Coventry, et al., "Ways of Seeing"; Linda Adler-Kassner, John Majewski, and Damian Koshnick, "The Value of Troublesome Knowledge: Transfer and Threshold Concepts in Writing and History" 26 (Fall 2012), https://compositionforum.com/issue/26/troublesome-knowledgethreshold.php.

${ }^{6}$ Paula Sutter Fichtner, "When Writing Comes across the Curriculum to History," Perspectives on History, American Historical Association, November 1, 2000, https://www.historians.org/publications-and-directories/perspectives-on-history/november-2000/ when-writing-comes-across-the-curriculum-to-history.

${ }^{7}$ Susan A. Ambrose, et al., How Learning Works: 7 Research-Based Principles for Smart Teaching (San Francisco: John Wiley \& Sons, Inc., 2010), 3.

8 "Why Include Writing in My Courses?," The WAC Clearinghouse, accessed February 17, 2021, https://wac.colostate.edu/ resources/wac/intro/include/; Janet Emig, "Writing as a Mode of Learning," College Composition and Communication 28, no. 2 (1977): 122-28; Sondra Perl, "The Composing Processes of Unskilled College Writers," Research in the Teaching of English 13, no. 4 (1979): 317-336; Linda Flower and John R. Hayes, "A Cognitive Process Theory of Writing," College Composition and Communication 32, no. 4 (1981): 365-387; Council of Writing Program Administrators, National Council of Teachers of English, and National Writing Project, "Framework for Success in Postsecondary Writing," January 2011; Linda Adler-Kassner and Elizabeth Wardle, eds., Naming What We Know: Threshold Concepts of Writing Studies (Boulder: University Press of Colorado, 2015); Linda Adler-Kassner, et al., "Principles for the Postsecondary Teaching of Writing," Conference on College Composition and Communication, March 2015, https://cccc.ncte.org/cccc/resources/positions/postsecondarywriting.

${ }^{9}$ Kathleen Yancey, Introduction to Adler-Kassner and Wardle, Naming What We Know, xvii.
} 
"the study of composed knowledge." ${ }^{10}$ At its core, the field is concerned with "what students should learn about writing, how they should learn those things, and how those things should be taught and assessed." ${ }^{11}$ Faculty in rhetoric and composition are interested in:

What composed knowledge looks like in specific contexts; how good and less-than-good qualities of composed knowledge are defined, by whom, and with what values associated with those definitions and qualities; how to help learners compose knowledge within specific contexts and with what consequences for learner and context; the relationships between technologies and processes for composing knowledge; connections between affordances and potential for composing knowledge; and how completed knowledge can be best accessed and why. ${ }^{12}$

Rhetoric and composition is a field that has been researching and teaching the writing process for over sixty years, and historians have much to gain by partnering with rhetoric and composition scholars in several ways, such as applying writing studies research to:

- develop writing assignments that are aligned with course outcomes and goals and match students' writing abilities.

- design writing assessment tools that measure students' learning.

- apply efficient but meaningful grading and feedback strategies.

- integrate writing instruction into the history classroom without sacrificing content.

As Antonova notes, many historians have "little direct training" in writing instruction. ${ }^{13}$ However, it does not need to remain this way. We believe a partnership between history and rhetoric and composition can help close that gap.

\section{Recommendation \# 1: Using Process Writing to Facilitate Learning}

The first major reassessment we propose is a shift from regarding student writing as an end product, most commonly represented through end-of-the-term essays, to teaching the writing process as iterative. In Donald Murray's seminal article, "Teaching Writing as a Process and Not Product," he explains the writing process is "the process of discovery through language. It is the process of exploration of what we know and what we feel about what we know through language. It is the process of using language to learn about the world, to evaluate what we learn about our world, to communicate what we learn about our world." ${ }^{14}$ It is with this emphasis in mind we offer the following recommendations to university faculty.

\section{Weekly Online Discussion Thread Posts}

We recommend faculty balance-or replace entirely, depending on the goals of the course-historiographical or research essays with daily or weekly online discussion posts. Daily or weekly online discussion posts teach students to process complex concepts and sources in a low-stakes environment in ways that high-stakes writing assignments, such as research essays or midterms, do not. As well, discussion posts provide the space for students to grapple with the course content, to track their learning over time, and to transfer their learning

\footnotetext{
${ }^{10}$ Adler-Kassner and Wardle, Naming What We Know, 1.

${ }^{11}$ Adler-Kassner and Wardle, Naming What We Know, 2; Linda Adler-Kassner, et al., "Principles for the Postsecondary Teaching of Writing."

${ }^{12}$ Adler-Kassner and Wardle, Naming What We Know, 1.

${ }^{13}$ Antonova, The Essential Guide to Writing History Essays, xv.

${ }^{14}$ Donald M. Murray, "Teach Writing as a Process Not Product," The Leaflet, November 1972, 4.
} 
across modalities. ${ }^{15}$

I assign weekly discussion posts in which students react to the readings in a 500-word post before a more detailed in-class discussion (Appendix A). ${ }^{16}$ For example, in my 200-level Disease in Early America course at the University of Denver, I asked my students to "describe how the conditions of slavery caused or exacerbated disease," using sources to support their claims (Appendix A). Student 1 wrote,

I think that the conditions of slavery can also expand to apply beyond physical diseases and validate other areas of their society as contaminated - including ideologies imposed by the terribly skewed perception of slave owners. For example, I was particularly stricken by this idea that there is a disease that causes slaves to run away - highlighted in the Cartwright reading. He notes that "the cause...is as much a disease of the mind as any other species of mental alienation" (Cartwright, 707). I found it truly ironic that such individuals are unable to comprehend the savagery of their own actions and instead blame biological disease as the catalyst for running away. ${ }^{17}$

Student 2 wrote,

What I found most interesting about this article was Savitt's description of how and why slave owners worked to improve these conditions. Savitt details the measures taken to prevent outbreaks of disease within slaves' living quarters, one of those being refraining from hiring out slaves to temporary or urban sites, as the spread of disease was much more common there (Savitt, 82). He explains the basic logic of infection within slave quarters, how it spread quickly from individuals to family and between families. Once there was an epidemic amongst slaves on a plantation, the odds were high that the slave owner or his family would come in contact with the disease. Additionally, a sick slave is not a productive worker, and having multiple slaves out of work would damage the slave owner's profits. So, slave owners were forced to improve the living conditions of their slaves not because they cared for their wellbeing, but because they were worried about their profit margin and the potential of their families getting sick. This is sad and horrifying, but I also think that it fits with the way many White Americans, particularly white slave holders, viewed Black Americans. Not as what they were humans with feelings, thoughts, dreams, relationships, etc., but solely as commodities and tools to increase their own wealth and success.

These examples show how students practice applying their learning, course readings, and personal understanding to course content. Open-ended critical thinking prompts like this one "invit[e] people to wonder," SOTL scholar Stephen D. Brookfield explains. "Wondering, of course, can then lead to all kinds of alternative possibilities being envisioned." ${ }^{18}$ Giving students time to regularly engage with difficult course material through regular writing teaches them to organize their thoughts clearly and to reconsider their preconceived ideas or previous learning about a topic. And the lengthier word count teaches them to develop their ideas, which prepares them to write longer, sustained writing assignments.

Discussion posts, as one possible example of the writing process, are an accessible way for students to process their ideas and course content in a format that allows them to own their reactions, confusions, and questions without fear of "making a mistake," "getting it wrong," or "getting a bad grade," which students have

\footnotetext{
${ }^{15}$ Whitney Blankenship, “Using Online Discussion Forums to Engage Students in Historical Inquiry," Social Education 7, no. 3 (2009): 4.

${ }^{16}$ When the text shifts to first-person, we are referring to David's work in the classroom.

${ }^{17}$ All student excerpts are truncated but unedited.

${ }^{18}$ Stephen D. Brookfield, Teaching for Critical Thinking: Tools and Techniques to Help Students Question Their Assumptions (San Francisco: Jossey-Bass, 2012), 196.
} 
told us stifles their writing and learning. Compositionist Heidi Estrem writes, "Understanding and identifying how writing is in itself an act of thinking can help people more intentionally recognize and engage with writing as a creative activity, inextricably linked to thought. We don't simply think first and then write.... We write to think." ${ }^{19}$ Similarly, Herbert A. Simon, one of the founders of cognitive science and a Nobel Laureate, explains, "Learning results from what the student does and thinks and only from what the student does and thinks. The teacher can advance learning only by influencing what the student does to learn." ${ }^{20}$ We encourage history faculty to consider how they might adopt discussion thread posts as homework to complement in-class discussions, to teach critical thinking, and to learn through the writing process.

\section{Regular In-Class Writing}

Another approach to teaching history through the writing process is through regular in-class process writing, such as five to ten minutes every class period. Regular writing is necessary for writers to improve. According to compositionist Kathleen Blake Yancey, "What we practice is who we are; if we want to be writers, we need to write. And in the practice of writing, we develop writing capabilities, among them the ability to adjust and adapt to different contexts, purposes, and audiences." ${ }^{21}$ As students regularly write in-class and out-of-class, faculty will notice improvement in students' comprehension and retention of course material, which is often lacking in final term papers. ${ }^{22}$ I will often ask an open-ended question prompting application and reflection that students will answer through in-class writing. For example, in my 200-level Disease in Early America course, I ask students to spend 5 minutes answering the question, "What are some similarities or differences between the 1832 cholera outbreak and the Covid-19 pandemic?" Student 3 focused on the ways in which blame for contagious disease is assigned to marginalized communities:

I think it is interesting how people [in 1832] focused on the idea that "Cholera was sent by God as punishment." It is interesting that people tend to feel much better when they have an apparent source of the problem to blame. Unfortunately, not everyone accepted the fact that this was simply divine intervention, and turned to blaming the poor for how they lived. Of course, the poor were not at fault, as they did not have proper resources/education to practice proper sanitation. It is especially terrible to see people doing this with COVID-19, as they blame Asian people for "creating" the virus.

Student 4 noticed that differences between the two outbreaks nevertheless demonstrated continuities and similarities:

I think it is especially interesting to think of how transport and technology helped spread cholera. The lack of knowledge and understanding of disease helped facilitate its spread through initially unchecked travel and the poor sanitary conditions. Yet today, the Covid-19 disease spread rapidly though the world in its most technologically advanced nations, and people were made to organize themselves to limit transmission of the disease-yet despite the widespread publication of the risks of the disease, many people want to ignore the scientific evidence and go back to business as usual—even though the disease apparently spread like wildfire when there was business as usual.

Open-ended questions that students write about in class reinforce the material while giving them a chance to

\footnotetext{
${ }^{19}$ Heidi Estrem, "Writing Is a Knowledge-Making Activity," in Naming What We Know: Threshold Concepts of Writing Studies, ed. Linda Adler-Kassner and Elizabeth Wardle (Boulder: University Press of Colorado, 2015), 18.

${ }^{20}$ Herbert A. Simon, quoted in Ambrose, et al., How Learning Works, 1.

${ }^{21}$ Kathleen Blake Yancey, "Learning to Write Effectively Requires Different Kinds of Practice, Time, and Effort," in Naming What

We Know: Threshold Concepts of Writing Studies, ed. Linda Adler-Kassner and Elizabeth Wardle (Boulder: University Press of Colorado, 2015), 64.

${ }^{22}$ Yancey, "Learning to Write Effectively Requires Different Kinds of Practice, Time, and Effort.
} 
gather their thoughts for discussion. Ultimately, such writing stimulates student engagement with the material, helping them notice the significance of new material to their own personal experience and future.

\section{Scaffolding Final Assignments with Process Writing}

For faculty who require final writing assignments like historiographical or research essays, we encourage faculty to emphasize the writing and learning process through assignment scaffolding. Rather than merely assigning a final essay and leaving it up to the students to complete it by the deadline, we recommend faculty integrate important intermediate milestones in the writing process into the curriculum. These can include the proposal, the annotated bibliography, the outline, discussion thread posts, and/or a rough draft accompanied by peer review. Scaffolding process writing pieces ensure students do not procrastinate through the research and writing process and provides a generative space for students to practice and refine their arguments and analysis. As Murray urges, "Instead of teaching finished writing, we should teach unfinished writing, and glory in its unfinishedness. We work with language in action." ${ }^{23}$ A writing process mindset allows faculty and students to experience (and hopefully enjoy!) the learning process through the writing process.

For example, in my 300-level Antebellum America course at Colorado State University, I assign a museum exhibit as a final project in addition to process writing. To scaffold the museum exhibit assignment, I also assign a project proposal, a primary and secondary source annotated bibliography, a rough draft, and peer review before the final exhibit is due. Each of these assignments is graded for completion according to the instructions, giving students a chance to accumulate points in a way that encourages them to stay on track rather than wait until the very end of the semester to complete the project. To reinforce the learning and writing process as iterative, I make sure to teach students how to conduct research and to evaluate sources throughout the course. Students thus have a chance to practice, to make mistakes, to refine, and to revise, which supports their learning in ways that hastily researched and written final projects do not.

\section{Recommendation \#2: Teaching the Writing and Learning Process Through Metacognition}

For faculty who find themselves asking questions like "What are students learning in my classes?", we recommend adopting metacognitive reflection throughout the term or as an end-of-the-term assignment. ${ }^{24}$ Asking students to participate in metacognition, defined as thinking about thinking, is critical to the learning process because it asks them to articulate what they are learning or have learned. ${ }^{25}$ Yancey calls reflection "a mode of behavior indicative of growth of consciousness" and defines three processes necessary for reflection: (1) "goal-setting, revisiting, and refining"; (2) "text-revising in the light of retrospection"; and (3) "the articulation of what learning has taken place, as embodied in various texts as in the processes used by the writer." ${ }^{26}$ As an integral part of the learning and writing process, metacognitive writing teaches students to take ownership for their learning. In this section, we offer two ways faculty might incorporate reflection into their classrooms.

\section{Daily or Weekly Reflection}

Faculty can integrate reflection-based process writing into the day-to-day classroom activities, such as twoor three-minute free writes at the beginning of class or at the end of class, in which students articulate the most salient point or lingering question they have about the course lecture or reading. For example, faculty might ask students, "What do you still find confusing about today's lecture?" and have students turn in their reflections at the end of the class period. Or faculty might ask students, "How might you apply what you learned from this week

\footnotetext{
${ }^{23}$ Donald M. Murray, "Teach Writing as a Process Not Product," 4.

${ }^{24}$ Wondering what students have learned in their classroom is a recurring concern among history faculty. For example, see Gary

J. Kornblith and Carol Lasser, "Beyond Best Practices: Taking Seriously the Scholarship of Teaching and Learning," Journal of American History 92, no. 4 (March 1, 2006): 1356.

${ }^{25}$ Aimee A. Callender, Ana M. Franco-Watkins, and Andrew S. Roberts, "Improving Metacognition in the Classroom through Instruction, Training, and Feedback," Metacognition and Learning 11, no. 2 (August 1, 2016): 216.

${ }^{26}$ Kathleen Blake Yancey, Reflection in the Writing Classroom (Logan: Utah State University Press, 1998 ), 5, 7.
} 
to your other classes, to your personal life, and/or to your professional interests?" or "What similarities are you seeing between the news and the 1832 cholera outbreak?" However faculty choose to have their students reflect, we recommend faculty regularly collect their students' reflection writing to see what connections students are making, to inform upcoming lectures, and to fill gaps in students' comprehension or application.

\section{Replacing Exams and Final Research Papers with Reflection}

In general, we recommend replacing traditional evaluations like blue book exams, scantron tests, or essays with reflection-based assignments (Appendix B). Reflection assignments, which can be assigned at the end of every unit, as a midterm, or as a final exam, teach students to take ownership for their learning and provide valuable feedback to faculty about what questions students still have and/or what course content was the most salient. End-of-the term or midterm reflection prompts might include any number of tasks:

- students describe what they have learned and explain the personal significance of this newfound knowledge.

- students engage with the course outcomes, such as identifying which course outcomes they grappled with or which course outcomes they feel taught them the most.

- students reflect on the specific, salient readings that shifted their perspectives, worldviews, or ideologies.

- students explain connections they see between current events and course content.

- students articulate how they can or will apply what they have learned in their personal lives, their professional lives, or in their other coursework.

To illustrate examples of how reflections support student growth, we include the following student excerpts from two courses I taught at the University of Denver in the spring quarter of 2020. The first two examples are from a non-major 200-level "Disease in Early America" course where I asked students to complete the quarter by writing an end-of-the-quarter reflection (Appendix B). Student 5 first reflected on the newness of their recently acquired knowledge:

[Learning about] smallpox and the relations between Europeans and Native Americans was very eye-opening to me because it exposed a side of history I had little to no knowledge about before. As I was learning about not only smallpox, but also the beginnings of colonization, I felt that my education up until this point had failed me. I was not aware of how smallpox affected the Native American population, and more generally, I had no clue that the Europeans were so cruel to the Native Americans.

Similarly, Student 6, also enrolled in "Disease in Early America," continued by reflecting on the significance of learning this new material in light of present-day events:

Taking this class during the Covid-19 pandemic was especially helpful in my understanding of the pandemic. I was able to understand more about disease and why we react the way we do in a pandemic. The readings in this class for smallpox and cholera epidemics showed that the public has not changed much in their reaction to disease. We have always reacted with denial and panic, resulting in blaming groups based on racial/socio-economic differences.

Finally, Student 7, enrolled in the 200-level non-major "History of Alcohol, Drugs, and Addiction" course, reflected on the role of their own positionality in their ability to process new information and knowledge:

Undoubtedly the consequences of the issue of race, in relation to mass incarceration and the development of the war on drugs took on more meaning in the last week of the course.... As a non- 
American white European attempting to understand the seemingly unique dilemma that exists in the US, it was...easier to understand through focusing [on] the readings from the course, in the context of the shooting of Breona Taylor, in a botched narcotics no-knock raid, that took place on March $13^{\text {th }}$ [2020] in Kentucky.

The final course reflection gave students an opportunity to consciously grapple with difficult historical questions regarding gender, race, and class, many of which they were encountering for the first time. Both courses were taught against the backdrop of the Covid-19 pandemic and George Floyd's murder and subsequent protests, and students were able to draw connections between course content and current events. Through such process writing as end-of-the-term reflections, faculty can learn about students' learning and reflect on their own teaching methods and course design.

Regardless of the form that metacognition takes in faculty' classrooms, as the term progresses, faculty will notice many students will intuitively begin to demonstrate a cumulative understanding of the material by engaging with themes and readings from earlier in the course. We encourage faculty to use students' reflections to inform their curriculum and calendar for the following term. Teaching students to engage in metacognition through writing positions them as co-creators of their knowledge and not passive recipients, which has positive effects on student retention, persistence, and academic success. ${ }^{27}$

\section{Recommendation \#3: Teaching the Writing Process By Focusing on Content}

As students engage with the complex concepts and skills in the history classroom, faculty will see students struggle with grammar, sentence structure, idea development, and organization while they are processing and remembering new terminology, methodologies, and skills. However, this is not a reason to stop integrating writing into the classroom, and it is not a reason to grade students' writing severely. These errors are a natural part of how the brain processes new information. According to educational psychologists Fred Paas, Alexander Renkl, and John Sweller, "Working memory, in which all conscious cognitive processing occurs can handle only a very limited number-possibly no more than two or three-of novel interacting elements." 28 As students work through their learning of new information, previously learned skills will be forgotten within the moment, including spelling, grammar, and word choice. With this in mind, we provide specific grading recommendations for faculty to mitigate the burden of grading while also remaining true to the spirit of the writing process as messy and iterative but invaluable.

\section{Giving Full Credit and Minimal or Zero Comments to Support Students' Learning Process}

Psycholinguist Frank Smith writes in "Myths of Writing" that writing is not just "for the transmission of information" but to "create experiences and to explore ideas." Similarly, Peter Elbow in "High Stakes and Low Stakes in Assigning and Responding to Writing" explains, "The goal of low stakes assignments is not so much to produce excellent pieces of writing as to get students to think, learn, and understand more of the course material." ${ }^{30}$ Faculty may need to pivot their thinking about the writing process as always polished and perfect to the messiness of the writing process and adopt a writing process mindset. ${ }^{31}$ In a writing process mindset, faculty

\footnotetext{
${ }^{27}$ Andria Young and Jane D. Fry, "Metacognitive Awareness and Academic Achievement in College Students," Journal of the Scholarship of Teaching and Learning 8, no. 2 (May 2008): 1-10; Matthew Kaplan, et al., eds., Using Reflection and Metacognition to Improve Student Learning: Across the Disciplines, Across the Academy (Sterling, Virginia: Stylus Publishing, 2013).

${ }^{28}$ Fred Paas, Alexander Renkl, and John Sweller, "Cognitive Load Theory and Instructional Design: Recent Developments," Educational Psychologist 38 (June 8, 2010): 2.

${ }^{29}$ Frank Smith, "Myths of Writing," Language Arts 58, no. 7 (1981): 792.

${ }^{30}$ Peter Elbow, "High Stakes and Low Stakes in Assigning and Responding to Writing," New Directions for Teaching and Learning 1997, no. 69 (1997): 5.

${ }^{31}$ Melissa Hudler, "The Messy and Unpredictable Classroom,” Faculty Focus, October 14, 2013, https://www.facultyfocus.com/ articles/teaching-and-learning/the-messy-and-unpredictable-classroom/.
} 
focus on students' learning through the writing process. Students' ideas, primary and secondary source use, source analysis, etc., not sentence structure or grammar, should take precedent in this process. It is important for faculty to remember that process writing will be, as popular writer Anne Lamott likes to say, "a shitty first draft" as all first drafts will be. ${ }^{32}$

We draw our grading recommendations from compositionists Peter Elbow and Richard R. Haswell's decades-long research on grading and commenting on students' writing. For the lowest stakes of writing, such as process writing, Elbow recommends assigning a grade with no response from the faculty. He explains, "Most students come to appreciate the chance to write with the knowledge that they will be heard but will not have to deal with my response. In fact, many teachers require some low stakes writing that they don't even read. Students can appreciate and benefit from the freedom of this private writing." ${ }^{33}$ Similarly, Haswell adopts a "minimal marking" approach to grading low-stakes writing, which "relegates what I consider a minor aspect of the course to a minor role in time spent on [grading]." ${ }^{34}$ In the zero response or minimally marked approach, faculty grade based on how well students meet the assignment objectives, including idea development, engagement with sources, organization of ideas, etc. Another approach would be for faculty to give all students credit for their process writing if students put in a good faith effort.

\section{Commenting on Content Rather Than Grammar}

For faculty who want to comment on students' writing, which is especially important for key pieces of process writing that lead to final drafts or on the final drafts themselves, we understand responding to student writing can be tedious for faculty. The intellectual, emotional, and cognitive labor of grading writing is often reported as the least enjoyable part of academic work and reasons why faculty do not assign more writing in their courses. ${ }^{35}$ Furthermore, students often cannot process all of the comments faculty leave on their writing and, in their own frustration, stop reading or do not incorporate comments into their revised drafts.

When providing feedback on students' process and high-stake major writing assignments, we take what Elbow calls "a supportive response," where faculty give students positive feedback about what is working well and, thereby, what students should continue doing in their writing. We also take "a redirected yet supportive response," where faculty make one or two comments that redirect students' thinking about an idea or correct misinterpretation within a supportive response. ${ }^{36}$ These two approaches free faculty from spending an exorbitant amount of time wrestling with grades and nitty-gritty feedback.

When responding to students' process writing, we take a minimal feedback approach to support students' learning without overwhelming them while they are in the midst of processing. My comments focus on reminding students of important assignment parameters (see Appendix A for example parameters) like "make sure you include citations in your next post" to teach students to engage with sources and properly attribute the work of others and "remember to break up multiple ideas into separate paragraphs" to teach clear organization. I also offer comments like "I'm not sure what you mean by X. An additional example or two will support your main argument" to teach idea development and supporting the main argument with clear and relevant examples.

When grading final writing assignments, we recommend faculty focus their feedback on two or three main

\footnotetext{
${ }^{32}$ Anne Lamott, Bird by Bird: Some Instructions on Writing and Life, 2nd edition (New York: Anchor, 2019), 20.

${ }^{33}$ Elbow, "High Stakes and Low Stakes in Assigning and Responding to Writing," 9.

${ }^{34}$ Richard H. Haswell, "Minimal Marking," College English 45, no. 6 (October 1983): 603.

${ }^{35}$ Deborah J. Cohan, "Advice for Grading More Efficiently," Inside Higher Ed, February 11, 2020, https://www.insidehighered. com/advice/2020/02/11/advice-grading-more-efficiently-opinion; John Tierney, "Why Teachers Secretly Hate Grading Papers," The Atlantic, January 9, 2013, https://www.theatlantic.com/national/archive/2013/01/why-teachers-secretly-hate-gradingpapers/266931/.

${ }^{36}$ Elbow, "High Stakes and Low Stakes in Assigning and Responding to Writing"; Richard H. Haswell, "Minimal Marking"; Richard Haswell, "The Complexities of Responding to Student Writing; or, Looking for Shortcuts via the Road of Excess," Across the Disciplines: A Journal of Language, Learning and Academic Writing, https://wac.colostate.edu/docs/atd/articles/haswell2006. pdf.
} 
areas, such as idea development, organization, analysis, use of sources, and genre conventions, among other global recommendations. ${ }^{37}$ If faculty are writing marginal and end comments, we recommend all comments focus on the same two or three main areas of feedback to ensure consistency and to reduce overwhelming and confusing students. To close the loop on major writing assignment feedback, we recommend faculty encourage students to apply their feedback to future drafts or future homework with phrases like "In the next assignment, I want you to focus on developing your thesis with evidence and analysis" or "When you write your next forum post, work on developing clear and specific topic sentences that connect back to your thesis." Such feedback shows students that faculty's comments should be applied to future writing assignments and are not simply in defense or support of a grade.

This grading approach does not mean I never respond to factually incorrect information. For example, I once graded a discussion post in a 300-level Civil War course at Colorado State University in which the student confused the Union and the Confederacy when describing the Battle of Shiloh. In a discussion post that otherwise met the assignment requirements, I wrote a short comment correcting the mistake without deducting any points for it. My approach showed the student I understand they are in the midst of learning. I reduce the stigma of mistakes - a stigma that often prevents students from fully engaging in course material, building relationships with faculty, and asking questions or asking for help-by signaling I understand that mistakes and confusion will happen as a part of the learning process.

\section{Identifying Grammar and Writing Style Choices that Can Be Taught}

We recognize some faculty worry their students' writing will falter if they do not comment or grade on grammar and punctuation. Moreover, some faculty may worry that process writing gives students free reign to write "badly." We acknowledge these concerns. A writing process mindset necessarily deemphasizes grammar because the emphasis is on learning through content development. In writing process tasks like discussion posts, in-class free writes, and other informal writing assignments, the writing is often impromptu and, therefore, less polished than high-stakes assignments, such as a midterm reflection. When faculty predominantly focus on students' grammar and writing style rather than their ideas, students also shift their focus from learning to grammar. ${ }^{38}$ As social studies teacher Tony Winger writes, "If higher-order thinking matters most, then that is what our grades must assess, record, report, and reward." 39 Finally, focusing on the content rather than the grammar and writing style frees students to write freely. Our experience teaching thousands of undergraduate students has shown us students' preoccupation with (and fear of) style and grammar contributes to writers' block, procrastination, and dislike for writing. Ultimately, a writing process mindset shifts faculty and students' attention away from grammar and back to students' learning. However, for faculty who want to respond to grammar and writing style, we have two primary recommendations.

First, we recommend faculty teach grammar and writing style in accordance with audience expectations and genre conventions. ${ }^{40}$ For example, if faculty have assigned a historiography essay, we recommend faculty take the time in class to discuss writing style and genre conventions expected by historians, as audience expectations and genre conventions often shift across disciplines. When faculty grade high-stake writing assignments, we recommend they comment on one or two areas where students need to revise their writing style to match the audience expectations. Additionally, to reduce the workload of writing the same comment on all students'

\footnotetext{
37 “Commenting on and Grading Student Writing," The WAC Clearinghouse, accessed February 18, 2021, https://wac.colostate.edu/ resources/teaching/guides/commenting/.

38 "Commenting on and Grading Student Writing"; Joseph M. Williams, "The Phenomenology of Error," College Composition and Communication 32, no. 2 (May 1981): 152-168; Nancy Sommers, "Responding to Student Writing," College Composition and Communication 33, no. 2 (1982): 148-156.

${ }^{39}$ Tony Winger, “Grading What Matters," Educational Leadership 67, no. 3 (November 2009): 75.

${ }^{40}$ Laura R. Micciche, "Making a Case for Rhetorical Grammar," College Composition and Communication 55, no. 4 (June 2004):

716; Williams, “The Phenomenology of Error," 152; Deborah Dean, Genre Theory: Teaching, Writing, and Being (Urbana, IL: National Council of Teachers of English, 2008).
} 
writing, faculty might identify one or two grammatical errors all students struggled with in a particular writing assignment and teach them as a class how to identify those errors in their writing.

Second, we recommend faculty do not cross out or line edit students' writing. Crossing out or line editing students' writing does not teach students to identify and revise their own writing errors, which are both integral skills to the writing process. As well, crossing out or line editing causes students to feel their writing has been written over by their professors, which causes students to lose confidence in their writing. ${ }^{41}$ For students whose writing impacts reading comprehension, we recommend encouraging students to visit the university Writing Center. Leaning on the Writing Center in this way frees faculty to focus their energy on students' content, comprehension, and critical analysis. However faculty decide to grade and comment on grammar and writing style, students need continual practice identifying and fixing grammar and writing style issues on their own. ${ }^{42}$

A final note on grading, grammar, and writing style: Grammar can be hard to teach (and hold students accountable for) because the English language is always changing and because English language speakers do not always agree on grammatical correctness or grammatical error. ${ }^{43}$ This does not mean faculty should completely disregard teaching, commenting on, and grading grammar. But it does mean when faculty attend to their students' grammar and writing style, they should be cognizant that "good," "correct," and "clear" grammar and writing style are not universally agreed upon across faculty, departments, and English-speakers.

\section{Recommendation \#4: Valuing the Writing Process in the Grade Distribution}

To truly value the writing process as an integral extension of the learning process, faculty need to value the writing process in their grade distributions. Whether faculty are teaching at an institution that assigns traditional letter grades or are teaching at an institution that does not assign grades, students need to know their writing matters. For faculty teaching in-person, we recommend devoting $10 \%$ to upwards of $30 \%$ of their total course grade for the writing and learning process. Faculty who teach online might weight process work as high as $50 \%$ of the final course grade, especially if students are producing 500-1000 words a week through discussion thread posts, drafts, outlines, etc. Furthermore, we recommend a "Process Work" grade category, which includes homework, in-class writing, peer review, etc., which shifts the emphasis away from "homework" or "quizzes" and affirms the importance of the writing and learning process. Over the course of the term, faculty can destigmatize the messiness of the learning and writing process by explaining why process work is integral to students' learning. For faculty who want to learn more about process work grade weight and distribution, we recommend meeting with your institution's Writing Center faculty, writing program faculty, or teaching and learning center faculty. ${ }^{44}$

\section{Conclusion}

We agree with Antonova's call for university historians to professionalize themselves in the teaching of writing in the history classroom. Because writing is a life-long learning process, teaching writing should

\footnotetext{
${ }^{41}$ Constance Weaver, "Teaching Grammar in the Context of Writing," in Lessons to Share on Teaching Grammar in Context, ed. Constance Weaver (Portsmouth, NH: Heinemann, 1998), 54-55.

${ }^{42}$ Richard H. Haswell, "Minimal Marking"; Dana Ferris and Barrie Roberts, "Error Feedback in L2 Writing Classes: How Explicit Does It Need to Be?," Journal of Second Language Writing 10, no. 3 (August 1, 2001): 161-184.

${ }^{43}$ Williams, "The Phenomenology of Error"; Misty Adoniou, "Grammar Matters and Should Be Taught - Differently," The Conversation, April 16, 2014, http://theconversation.com/grammar-matters-and-should-be-taught-differently-25604.

${ }^{44}$ Stephen Tchudi, ed., Alternatives to Grading Student Writing (Urbana, IL: National Council of Teachers of English, 1997); Barbara E. Walvoord and Virginia Johnson Anderson, Effective Grading: A Tool for Learning and Assessment in College, 2nd edition (San Francisco, CA: Jossey-Bass, 2009); John C. Bean, Engaging Ideas: The Professor's Guide to Integrating Writing, Critical Thinking, and Active Learning in the Classroom, 2nd edition (San Francisco: Jossey-Bass, 2011); Asao B. Inoue, Labor-Based Grading Contracts: Building Equity and Inclusion in the Compassionate Writing Classroom (Fort Collins, CO: CSU Open Press, 2019).
} 
be the responsibility of all faculty across the university. ${ }^{45}$ Even if universities require one or two English or writing courses as part of the general education curriculum, what students learn in one or two courses must be expanded and extended across their undergraduate education. Teaching discipline-specific writing is all of our responsibilities, and we hope readers are inspired and encouraged with practical ways to use the writing process to teach history.

While faculty may apply our recommendations differently across courses, we argue that no matter what form it takes, process writing is an essential pedagogical component that history faculty can use to help students take ownership of their education, learn to express their own unique voices and perspectives, and process complex ideas. Students need to write early and often to develop critical thinking skills, retain course content, and engage thoughtfully with troubling or controversial subjects. Ultimately, students who engage in process writing develop a sense of intellectual grit; the ability to grasp multiple, often competing points of view; and exercise their individual agency to become self-directed, life-long learners. Finally, and perhaps most importantly, incorporating process writing and metacognition into the undergraduate history classroom does not mean that grading writing needs to be laborious or mentally exhausting. History faculty no longer need to scramble to find ways to meaningfully incorporate writing in their classrooms. A writing process mindset liberates faculty to act as co-creators of learning and knowledge with their students.

${ }^{45}$ Ellen Goldberger, "Why All Faculty Need to Consider the Teaching of Writing Their Responsibility," Inside Higher Ed, April 24, 2014, https://www.insidehighered.com/views/2014/04/24/essay-why-all-faculty-need-consider-teaching-writing-their-responsibility. 


\section{Appendix A: Weekly Online Discussion Post, 200-Level Disease in Early America Course}

In approximately 500 words, describe how the conditions of slavery caused or exacerbated disease. Make sure you use examples of specific diseases in your answer. The post should include YOUR point of view, such as a distinct argument about the readings, a reflection on a course theme, or analysis of a specific source. Make sure you provide a detailed evaluation of the content you are posting about, not merely summarizing the readings. Draw on ideas and arguments in the readings as evidence to support your claims. Any ideas or direct quotes from the readings need to be explicitly cited using a parenthetical citation (Author, Pg. \#). Example: (Rosenberg, 3). Let me know if you have any questions about these instructions.

Discussion thread posts will be graded out of ten points according to the following criteria:

- 10 points = Above average: student expertly synthesizes and expands upon ideas and texts. Writing and organization is nearly flawless.

- 7 points = Average: student works with ideas and texts proficiently. There are some organizational, style, and/or clarity issues.

- 5 points = Below average: key ideas and citations are missing. There are multiple organizational, style, and/or clarity challenges that impede understanding.

- 3 points $=$ Post is incomplete.

- 0 points $=$ No post.

Discussion thread posting that are off-topic, rambling, misogynistic, sexist, racist, politically charged, etc., will be graded as a zero.

\section{Appendix B: Final Learning Reflection, 200-Level Disease in Early America Course}

In at least 500 words, reflect on what you learned in this course. This assignment asks you to engage in metacognition, defined as thinking about thinking. Researchers on metacognition say we have better memory, transfer of knowledge, and engagement when we participate in metacognition.

Therefore, instead of a final exam, the final learning reflection asks you to think about what you have learned this quarter, select specific examples of your growth, and explain the significance of this learning to how you understand the topics and/or the world around you.

In your reflection:

- Describe what you have learned.

- Explain the importance or significance of this new knowledge to you personally.

- Include at least THREE specific readings from the syllabus that stood out or spoke to you.

You are welcome to write a narrative or an essay. Whatever genre you choose, your reflection should include specific examples and analysis to illustrate your learning this quarter.

Your reflection should have an introduction, body paragraphs, and a conclusion (as we have been doing all quarter). This genre is not a research article or short analysis essay, so your writing style can be more informal. Think of it as being similar to your weekly discussion thread posts. The main thing is, I want to hear YOUR voice. If you want to read more about narrative features, head over here: https://leo.stcloudstate.edu/acadwrite/narrative.html.

Focus your learning reflection on any of the following themes:

- How diseases like smallpox shaped encounters between Native Americans and Europeans.

- The relationship between changing concepts of disease, epidemics (such as cholera), and the emergence of public health institutions.

- The experiences of women and enslaved people.

- Controversies regarding historical interpretation.

- Mental health, asylums, and the Civil War as a medical event.

- The difficulties of learning about these themes in a time of Covid-19. 